\title{
Migration and belonging in the home literacies of Mirpuri families
}

Book or Report Section

Accepted Version

Capstick, A. (2018) Migration and belonging in the home literacies of Mirpuri families. In: Bahun, S. and Petric, B. (eds.)

Thinking home: interdisciplinary dialogues. Bloomsbury, London. ISBN 9781350062375 Available at http://centaur.reading.ac.uk/76796/

It is advisable to refer to the publisher's version if you intend to cite from the work. See Guidance on citing.

Publisher: Bloomsbury

All outputs in CentAUR are protected by Intellectual Property Rights law, including copyright law. Copyright and IPR is retained by the creators or other copyright holders. Terms and conditions for use of this material are defined in the End User Agreement. 


\section{CentAUR}

Central Archive at the University of Reading

Reading's research outputs online 


\section{MIGRATION AND BELONGING IN THE HOME LITERACIES OF MIRPURI FAMILIES}

\section{TONY CAPSTICK}

\section{Introduction}

In this chapter, the home is the central domain from which I explore the writing of one Mirpuri migrant family from Pakistan. Mirpur town, in the Azad Kashmir region of Pakistan, is bound to the north west of England through three phases of chain migration, which have developed over the past 50 years. In the first phase (from the 1950s to the 1960s), male labour migrants left Azad Kashmir for the textile mills of Lancashire, and were quickly reunited by their wives and children in the family reunion phase (1960s to 1970s). With increasing curbs on immigration by successive UK governments, marriage migration became the means by which Mirpuris demonstrated their kinship responsibilities by marrying British Mirpuris, often in Mirpur, but then moving to the UK to live. It is during this contemporary phase of marriage migration that Usman (from Mirpur), whose home literacy practices are explored in this chapter, and Nadia (from Lancashire) came to be married. All three phases are explored in detail in a separate study (Capstick 2016a), which identifies the role of literacy in the chain migration. In addition to the dominant literacies of visa applications, in the larger study I found that the vernacular literacies of migration which emerged in Mirpuri migrants' writing on social media from the UK had originated within the borderlands of school and home in Pakistan. The current chapter takes up the notion of vernacular literacies of migration in order to explore the opportunities migrants have for reading and writing in the home and the extent to which these literacy practices relate to different homes, and different belongings in both countries. To do this, I take a longer historical 
perspective on these literacies which converged in the home in order to examine the social, cultural and political forces that shape contemporary practices.

Home literacies are therefore understood within the context of the institutional sponsorship of literacy, that is, those institutions which either prevent or promote literacy (Brandt 2001), in North West Pakistan prior to Partition in 1947. This is followed by an analysis of how this sponsorship shaped the availability of literacy in individuals' lives. The availability of literacy in Usman's life is explored by paying close attention to the home literacies, chiefly a diary of thoughts and quotations which he kept prior to his migration, including his own perspective on these practices which he gave during interviews about his home literacies. Combining the analysis of these literacy practices with an analysis of the construction of belonging in the diary extracts provides a vivid account of how Usman, who was nineteen years old when I met him, negotiates multiple individual and collective belongings prior to his arrival in the UK. It is Usman's home-based literacies that enable him to construct his sense of home in Azad Kashmir while beginning to forge a sense of belonging to his new home in Lancashire, UK.

\section{Methodology}

This study was carried out at a time when migrants' proficiency in the dominant language of the country they wished to settle in was increasingly being linked to their ability to integrate into the nation states of the West. At the same time that Usman was writing the diary entries discussed in this chapter and completing the visa application forms that would enable him to join his wife in the UK, the UK was introducing English language testing legislation for nonEEA nationals which compelled them to pass a test in English prior to applying for a visa. I 
first met Usman while carrying out ethnographic research in English language schools in Azad Kashmir, Pakistan. I interviewed students about their prospective migrations and recorded their use of literacy, looking at both the dominant literacies of visa applications as well as their vernacular practices on social media. Although visa literacies are central to transnational families' ability to maintain the kinship ties that have joined Azad Kashmir with the north west of England since the first male labour migrants began moving to the UK in the 1950s, I have found that there are also vernacular literacies of migration with which individuals engage. These are not related to the bureaucratic literacies of institutions, and they convincingly illustrate migrants' translanguaging as well as their transnationalism (Capstick 2016b). In order to find out to what extent families draw on the availability of literacy in Mirpur in their migrations, the study reported in the current chapter sought to identify how the availability of literacy provides opportunities to shape the identities at home. Gal and Woolard (1995) have suggested that ideologies which appear to be about language are often about political systems. I therefore explore the political decisions about language and literacy made in the region around Mirpur by tracing migrants' access to dominant languages such as Urdu and English at school. These literacies are then taken up at home when family members come together to share their literacy resources and generate new identities, and maintain or relinquish old ones in their literacy practices. This analysis rests on the notion that identities at a given moment in history are subject to change, like the ideologies that legitimize and value particular identities more than others (Blackledge and Pavlenko 2001). I draw on data collected with a key respondent in Mirpur prior to the acceptance of his visa application by the UK Borders Agency in order to explore how he uses the social and linguistic resources in his home literacies to both take up as well as resist identities. I do this by turning to the users of language, that is, the family 
members, to understand the relationship between views about language and its usage. I look specifically at what Usman told me about writing at home and school and what he felt about this writing, as I am interested in the interrelationship between what people believe about their practices and the way that they access and make use of their linguistic resources. In the interviews we conducted together we discussed the language and literacy choices of his in the collection of writings he made leading up to his migration, which I will call 'the diary'. The linguistic resources he draws on include Urdu, the national language of Pakistan, which is the official medium of instruction in state schools, as well as English, which is the official language of the country and is used increasingly in private as well as state sector schools.

This type of research raises significant issues around the ethics of working with migrant families at times in their lives that anonymity was particularly important to them. By providing interview information sheets on University letter-headed paper which explained the research project I was involved with and asking the interpreters to translate these orally if participants were unable to read them, I was able to comply with the University's ethics procedures and with the ethics procedures of my discipline, Applied Linguistics. Ethics are also central to the ethnographer's ability to make valid claims about the social world. Methodologically, data were collected with a rigour that enabled me to draw conclusions and make claims about the migrations I was investigating. In the wider study I have related this rigour to trust when carrying out interviews, as I was working in the homes of participants and thus the trust of the research participants had to be ensured. Again, I see it as central to the way that ethnographers think about reflexivity when addressing the conditions of their research participants' lived experiences and how this affects knowledge production both in the field and in the writing up of others' lives. In this sense, the methodological approach in this study connects with the anthropological approach 
of Rapport's chapter in the current volume. His interest in the capabilities of human beings 'to construct world-views for themselves, to make their own sense of the world around them, and to imagine a life-project of meaning and value within this world' (xxx), is very much the concern of the literacy ethnographer whose goal is to provide insights into the role of literacy in individuals' meaning-making by exploring the dialectical relationship between language and culture.

However, it is with specific reference to the manner in which Rapport deploys understandings of home which connect 'house to nation' that the current study has most in common with his anthropological approach. Such an approach to home necessarily informs my exploration of the role of literacy in connecting migrants to multiple 'national' identities.

\section{Literacy practices, identity and belonging}

Research in the New Literacy Studies tradition argues that literacy can only be understood in relation to its context. As a result, researchers from the 1980s onwards working in this tradition orient to the socially contingent nature of literacy. This has meant focusing on the ways that literacy conveys the values and attitudes of the individuals and groups of users of texts, and the processes involved in text production (Barton and Papen 2010). For Barton and Hamilton, the literacy practices of these users are seen as 'the general cultural ways of utilizing written language which people draw upon in their lives... However, practices are not observable units of behavior since they also involve values, attitudes, feelings and social relationships' (2000: 7). Taking this social practices approach to literacy demonstrates how literacy can be seen as a shared resource, shared across the communities which come together to use it. This approach also connects with work elsewhere in this volume which draws on Wilfred Bion's term of home as a container (Papadopouos, current volume). If we accept that the home impacts on three 
levels - the individual/family, the regulation of networks of inter-relationships, and as a mediator between these two levels and the outer world of society, culture and socio-political realitiesthen the role of literacy as a shared resource in a textually mediated world enables the ethnographer of literacy to trace the connections between these different levels. If the home is a key construct in these overlapping realms (Papadapoulos, current volume), then the means by which migrants take up opportunities for literacy to enable their migrations and maintain their belonging to home in a range of transnational settings enables anthropologists and ethnographers a lens through which to explore the role of literacy in the home as well as the role of home in literacy.

At this point it would be helpful to elaborate on how different settings and goals require different literacy practices for different communities of practice. When characterizing these new approaches to understanding and defining literacy, Street draws a distinction between an 'autonomous' model and an 'ideological' model of literacy (Street 1984). The former works from the assumption that literacy in itself will have effects on other cognitive practices while disguising the cultural assumptions that underpin it, presenting them at a later date as though they are neutral and universal. The ideological model posits that literacy is not simply a technical and neutral skill but that the ways we conceive of reading and writing are themselves rooted in concepts of knowledge, identity and being (Street, 1984). For Barton and Hamilton this means that there are different literacies associated with different domains of life, but that the home is the core domain to which other domains relate: 'it is a place where different aspects of life are negotiated and fitted in with each other. In this process new, hybrid practices are sometimes produced' (1998: 189). The role of the home as the 'core domain to which other domains relate' will be investigated in this chapter. In the first part of the analysis I explore how home literacies 
are shaped by institutional decisions which have been made outside the home by the sponsors of literacy who sanction the use of different language varieties through education and language policy. As Gee (2011) suggests, we need to look at where everyday language begins, and where it is primary in people's literacy lives and therefore central to people's developing sense of social identity.

In the second part of the analysis I continue to trace these historical, social and cultural forces by bringing the analysis of Usman's diary extracts together with work on 'belonging' in order to identify the shifts in identity that Usman constructs as he prepares to leave his home in Mirpur and join his wife's new home in Lancashire, UK. 'Identity' to Gee (2011) refers to the different ways of being in the world and is significant in this study as it is not a static notion of 'being' but one which changes at different times and in different places. Usman and his families' social identities are represented through their literacy practices and negotiated in ways which allow them to belong, or choose not to belong, to the social processes which connect people to multiple homes in Pakistan and the UK. This analysis will be developed through the notion of 'belonging' as part of what Krzyzanowski and Jones refer to as the 'sustained critique of the concept of identity' (2008:8). In their attempt to overcome the problem of allowing an analysis of identity to hide more than it reveals, the authors call for a 'conceptual unpacking' of identity to aid the multiple and complex processes associated with identity construction. Krzyzanowski and Jones employ a framework which looks at how patterns of belonging are constructed dynamically thereby helping situate an individual's position in relation to the collectivities of the community that the migrant has left as well as the community into which they have migrated. The focus in the second part of this chapter will be on Usman's belongings as he began to imagine his life in the UK by tracing his attachment to various belongings with different 
groups and, following Jones and Krzyzanowski, what this tells us about the relationship between a personalized identity and a collective one:

...belonging can be considered a process whereby an individual in some way feels some sense of association with a group, and as such represents a way to explain the relationship between a personalized identity and a collective one. In a purely conceptual way belonging is about the relationship between personal identity and a collective identity - there is something about one's personal belonging that is comparable to one's perception of the aims, constitution or values of a given collective. (2008: 44)

To explore the construction of these individual and group identities, I turn to the text world of Usman's diary as it is by connecting the personalized identity to the collective one that the notion of belonging enables us to explore the role of literacy in migrants' developing sense of home. According to Barton and Hamilton (1998), the text world refers to the literacy practices and expressions of identity related to an individual's writing in one sphere of activity. In Usman's case this was the text world of the diary which he completed as he waited to hear the decision about his visa application. In their analyses of the text world in their study of community life in Lancaster, UK, Barton and Hamilton focused on how people are presented by the author, what these people are doing, and what activities are ascribed to them. It is within this focus on people and their attributes that I embed work by Krzyzanowski and Jones (2008), who believe that, drawing from Probyn (1996: 19), the process of belonging captures the desire for attachment to people, places or modes of being. By exploring these attachments within the analysis of the text 
world, Usman's belongings emerge as part of his home literacies. As these were literacies which Usman engaged in immediately prior to his departure to England, they can be seen as what Fortier has called 'narratives of identity' which form part of the 'longing to belong' rather than surfacing from an already constituted identity (2000: 2). In this way, Usman's perceptions of belonging at a crucial point in his migration, which, Krzyzanowski and Jones suggest, display the 'process of becoming someone, rather than already being someone' (2008101), tell us about his attachments to the different collectives in his life at that point.

\section{Part 1: The access and availability of literacy in Mirpur}

Understanding literacy as social practice, Judith Kalman (2005) argues, means looking at how text users learn to respond to the specific requirements of participating in literacy activities. This she characterizes as access to literacy. Deborah Brandt's (2001) concerns are similar to those of Kalman's, though she suggests that it is the sponsors of literacy that both provide and prevent access to literacy. Both access/availability and sponsorship help us to understand how institutions shape what happens in the home as it is the sponsorship of literacy by schools in Pakistan and their use of dominant, formal and standardized literacy in Urdu and English which shape Usman's access to literacy at home. Understanding literacy in its broadest terms in this way means taking account of 'any agents, local or distant, concrete or abstract, who enable, support, teach and model, as well as recruit, regulate, or withhold literacy - and gain advantage by it in some way' (Brandt 2001: 27). As such, Brandt argues in her study of literacy in the US that print penetrates all areas of existence and thus only the most powerful countervailing forces are able to prevent access to it. In this section I explore how powerful countervailing forces have 
prevented access to literacy in Punjabi for speakers of the language in Pakistan while providing access to literacy in Urdu and English.

Usman's family, like most Mirpuris, speak a variety of Punjabi which is known as Mirpuri Punjabi. It is part of the Punjabi dialect chain and is spoken widely in Azad Kashmir as well as being spoken widely by Mirpuris in the UK (Lothers and Lothers 2007. However, Punjabi is not written by the vast majority of its speakers as it is Urdu which is the symbol of Muslim identity and which confers the prestige in Pakistan that Punjabi lacks (Rahman 1997; 2009; Rassool 2007). Given that Brandt (2001) has argued that literacy is part of larger material systems which help develop reading and writing while at the same time conferring their value, it is useful to understand how the de-valuing of Punjabi in institutional spheres has led to Punjabis use of other literacies at home, that is, until users of social media began using Romanized scripts in their transliterations of Punjabi online (see Capstick 2016b). Until these new self-sponsored vernacular literacies emerged, only a small number of Punjabis who learned how to read and write Punjabi at university were able to access literacy in their first language. Tariq Rahman (1997; 2009) has written extensively about this situation where most children in Pakistan are not taught through their mother tongues but through Urdu. He recognizes that, particularly in the early years, children's mother tongues are in fact used informally in classrooms to explain the lessons, code-switching to Urdu and English, the latter being the official language of the country and very much the language of power within the elite that runs the country.

\section{Usman's family's home literacies}

Usman's family is not part of this elite yet he likes to use English as often as possible in his everyday life. He was born in Pakistan close to the boundary with Azad Kashmir though his two 
brothers and one sister were born in different towns across the country as their father, a soldier, was relocated to different garrisons. Usman recalled that the army schools he attended promoted literacy in Urdu by rote learning but many of the teachers spoke English, whereas the English medium schools he attended were less consistent: many of the teachers promoted literacy in Urdu and English while using spoken Urdu with code-switching to English in the classroom. Punjabi, he told me, was only used by those teachers who did not know the words in English or Urdu, though the code mixing in this diglossic context is far more complex than this description allows. Usman recalled several grammar books that he kept and used at home with his brothers, as he found grammar books particularly useful for developing both his spoken and written English.

By visiting Usman's home I learned that the family kept a variety of written texts, most of which were related to the family's religious practices, schoolwork and English language learning. In Usman's home I saw lots of evidence of Usman's desire to learn about English. He almost always made a point of telling me who had recommended the family's books. These were normally people who Usman knew from around Mirpur but had not been teachers of his. The father of one of Usman's closest friends had not only recommended books but had also given Usman informal instruction in English at his home. Usman explained that he shared these books with his brothers. He felt a responsibility to help them both with their English language development. He did not see a need for his sister to learn English, though she too was learning at school. As part of the help Usman gave his brothers the young men would often sit down together to look through these books. Usman felt this was very important as he explained that schools did not always teach English properly. Here, literacy in English practised at home is related to the accessibility of literacy at school. When schools promote the availability of literacy 
in English through curricula, exams and written material in English, but simultaneously withhold access to literacy in English due to the lack of proficient teachers who know how to use either written or spoken English, family members find alternative ways to help each other.

Kalman's (2005) view is that family members of different generations take up new opportunities to participate in reading and writing events and to learn new literacy practices. These she calls literacy-scaffolding situations. Usman's family scaffold each other's literacy when doing homework together, an after-school activity. This provides Usman with opportunities to practise his English while at the same time giving his brothers opportunities to use their spoken and written English. As discussed earlier, Barton and Hamilton (2000) suggest that individuals move in and out of different domains and occupy the borderlands between them while changing their lives. They find the home is the core domain to which other domains relate, which makes the home central to the manner in which different aspects of life are brought together. This hybridity was extended by Usman's use of English with Nadia in England. Using a mixture of English and Mirpuri Punjabi with her when they chatted by Skype while completing the visa application forms together meant that the borderland was further blurred as the variety of English which Usman learned from Nadia was the local variety spoken in Lancashire, which has its own conventions, as well as the very different written variety of British Standard English which they were required to use when filling in the application forms for Usman's visa. Thus, access routes to literacy in English transformed the meaning of reading and writing from individual rote learning at school into a social activity accomplished through interaction at home. Home here is Usman's current family home in Mirpur as well as his new home with Nadia in Lancashire in the UK. Moving 'between' homes in this way is captured in the current volume by Papadopoulos who suggests that home can be understood as 'a container of complex inter- 
relationships between (a) space, (b) time, and (c) relationships' which are established over a period of time but which are not tied to geography (page number). Furthermore, the time aspect for Usman is not tied to a specific duration as he already identifies with his new home in the UK long before leaving Pakistan. This is because, as Papadopoulos points out, home refers to any space that can be experienced as intimate.

\section{Part 2: Belonging in Usman's home literacies}

Usman's diary included a variety of extracts copied from the Qur'an and the Hadith as well as his thoughts and feelings about his prospective migration interspersed with poetry, military slogans, dictionary definitions and quotations from songs. The extracts are rich descriptions of his recent marriage and his existing family relations. Usman told me that the reason he had written these entries was to help him 'think about things'. In this way, the diary is a written record of how Usman uses literacy in Urdu and English to make meaning of his life.

During the 12 months that Usman and I met to discuss his literacy practices, one week was spent talking about the diary. During that week we would sit together with the diary in front of us and he would first translate the extract. These interviews were audio recorded and I would also write down the translations on a separate copy of the diary. Once he translated any Urdu extracts I would ask him questions about what the extract meant to him and why he had chosen a

particular language or languages. This way we worked through all 43 pages of the diary page by page. During these interviews I was particularly interested in how Usman positions himself and others in the extracts as well as the reasons for his choice of language and the identity issues which these choices were related to. Many of the people who populate the diary are not known to 
Usman. Some are famous singers, others are military heroes, while many are Usman's family members.

\section{Caste, cousins and Kashmir: belonging to the family and its ancestral villages}

Usman's family is presented prominently on the first page of the diary (see Figure 11.1).

Usman's caste, Raja, is printed boldly at the top of the page, though in fact Usman told me that this had been written by his sister. He also told me that Raja is a very important caste in Pakistan and India and that he would not have been marrying Nadia if she had not been from a similar caste. Raja is written in English twice and in Urdu once. The significance of Usman's caste to his family relations and home in Azad Kashmir is made explicit from the start as there is a link between caste and the family members that he lists on the page. These relations are established by a collective identity which Usman constructs by listing his cousins. However, the collective identity of his friendship group is also foregrounded in the quote 'Band of Brothers', which he explained was the name given to his group of university friends who played sports together. These words and the words 'Welcome', 'give respect and get respect' as well as his own name are all written in English. Towards the bottom of the page, Usman dedicates the diary to his family. In English he describes them as 'the great and loving people', which orients Usman to a collective belonging with the wider family relations beyond Mirpur town. By mentioning three villages of his mother and father's families, Usman foregrounds this collective as primary in his home literacies. In the interviews where we spoke about these relations Usman explained that his cousins 'influenced me with everything you know from the cousin in [name of village] I kind of built myself into an educated person 'cause they all are educated well dressed and well-spoken 
so when I saw them that style they all do namaz and roza and [indistinct] and all that when I saw them they gave me inspiration you know to be a good person'.

Here Usman links the attributes of being a good person to education, dress, speech and prayer (namaz and roza). These are attributes that, in Usman's own words, inspire him. From the beginning of the diary it is clear that Usman orients to discourses about being a good Muslim. Moments later in the interview Usman tells me that these cousins, from Azad Kashmir, now live in Luton, UK. He also mentions that the cousins speak English well and that they all support their family 'at home in Azad Kashmir by sending money from England'. Home to Usman at this point in the diary is Azad Kashmir yet migration is already a significant part of his home literacies as the migrations of the cousins are part of the reason that he dedicates the diary to them.

[Figure 11.1 here]

Figure 11.1: The first page of Usman's diary (@ Palgrave Macmillan)

\section{The military, nationhood and religion: belonging in Pakistan}

Usman told me that the greatest disappointment in his life up to that point had been his rejection from the army. Having grown up in a family which had strong ties to the military (his father and many relatives had served in the army), in a disputed territory which often experiences conflicts with its neighbour India, Usman's great desire had been to join the army. He told me that he had not been given a reason for his application to be declined but after two years meeting with Usman in AK and the UK, it seemed to me that his migration was in some way an alternative to the life in the military that had been denied to him. It is with Usman's passion for the military in mind that his diary entries related to military texts must be considered. 
The majority of the extracts in the text world that Usman creates are related to the military. They are often direct copies of army slogans written in English or Urdu or both as the army sponsors literacy in both languages in Pakistan. Rassool (2007) suggests that English has retained its high status within the domains of power, including the military, since colonial times, due to its integration into Pakistani cultural, political and economic institutions. This can be seen in Extract 2 where Usman has taken the text from a poster he saw at the army offices when he visited to take his entrance test:

[Figure 11.2 here]

Figure 11.2: Extract 2 from Usman's diary (ㅇ Palgrave Macmillan)

Such was Usman's passion for the military that he kept a copy of this poster in his home. The theme here of the sacrifices made by soldiers for their country can be seen in the extract where 'we' is the Pakistan military and 'their' is the Pakistan nation. Usman told me that it was extremely important that the Pakistani military fought to keep Pakistan Muslim, and part of this fight was to keep Azad Kashmir in Pakistan. Usman orients to the military's dominant discourse of protecting the Pakistan state from the Hindu aggressor India. This is one of many similar quotations where Usman foregrounds the positive view of the deadly conflicts with India and signals his allegiance to the state of Pakistan. Other quotations are often translated from the original text in Urdu into English or were originally in English.

An example of this can be seen in Extract 2 where Usman inserts his own transliteration 'Sher dil' followed by the original Urdu script which is then followed by the English translation 'LION HEART'. He told me that this refers to the Pakistan Air Force, signalling an 
interdiscursive relationship between religion and nation. The discourse about religion is invoked in a discourse about fighting for Pakistan nationhood. Belonging to the nation of Pakistan is embedded within Usman's belonging to a Muslim collective.

These bilingual entries are also used by Usman to signal his belonging to the wider collective that is the state of Pakistan. In one entry he has copied the words 'Help is from God, victory is near', which he saw in Mirpur town, to which he has added underneath the ethnolinguistic identities of the different provinces of Pakistan. The inclusion of Kashmiri here signals Usman's orientation to the dominant discourse which ascribes the Kashmiri identity to Pakistan, even though ethnically and linguistically Mirpuris have more in common with Punjabis across the Jhelum river. In these home literacies, Usman creates his own intertextual links between the unity of the nation (Sindhi, Balochi, Punjabi, Pthan, Kashmiri), the military (Pak Army), and sacrifice (lion hearts.) Close to these entries, Usman has inserted a transliteration of Urdu in Roman script, Pak Fauj Kay Jawan'. Usman told me that this slogan is intended to inspire young people to join the army. Rassool (2007) has suggested that the hegemony of Urdu during colonization by the British was extended when it was selected as the national language of Pakistan thus confirming its centrality to the nationalist ideology of the country and what it means to be a Pakistani. Urdu came to represent what it meant to be a citizen of Pakistan, and as Pakistan was created as a home for the Muslims of post-partition India, thus Urdu became a key defining principle of being a Muslim in Pakistan. In other words, Urdu was central to the state's view of Pakistani nationhood.

These Islamic principles can be seen in many of Usman's extracts from the Qur'ran and Hadith, which Usman combines with his own fatalistic view of the world at this point in his life as several of his selected texts relate to Judgement Day. In one extract, the text is written in 
Urdu, under which Usman has written 'End of time' in English. The religious texts which Usman quotes can be understood in terms of the belongings he constructs to the collective of Muslims of which he is part. This collective identity is foregrounded in quotations which mark out Muslims as different from non-Muslims, again suggesting that Usman aggregates positive information on the object of his belonging 'excluding and deleting negative information and experiences which would undermine or distort this positive image' (Jones and Krzyaanowski 2008: 27). One example of this aggregation was Usman's comment to me about a quotation which suggests that the non-Muslim looks into the sky whereas for the Muslim the sky looks into him, Usman explaining: 'it means that you know er non-Muslims is more interested into the into the this world'. Usman went on to explain that Muslims are less concerned with worldly or material goods than non-Muslims. These comments and quotations can be seen as a desire on Usman's part to foreground his belonging to the worldwide collective of Muslims. Belonging to a state which promotes the military and martyrdom, but which is fundamentally Muslim, is therefore signalled in both Urdu and English in Usman's translations, where both languages signal his identification with Islam as well as the military. Given the significance of a Kashmiri ethnolinguistic identity in these postings, the following section explores the historical traces of Usman's language and literacy practices in order to establish how two languages, which are not native to Pakistan, are so inextricably bound up with his local and national belonging.

\section{Colonial sponsors of literacy in Urdu at the expense of Punjabi}

English, the ex-colonial language, is well entrenched in contemporary Pakistan because it has been the language of the domains of power in South Asia since British times and is still used in these domains (Rahman 2009). This is a result of the language policy in colonial northwest India, 
Diamond (2012) argues, which focused on the status and use, as well as misconceptions about that use, of languages available in the region. The 'official' policy at the time Britain was establishing itself as the colonial power referred to the use of language for administrative, and later educational, purposes, though for early colonial officials, decisions about language policy were an important aspect of colonial administrators' wider concern about administering the region. For Diamond, the sponsorship of literacy in languages decided by the administration was a top-down affair which had considerable ramifications for the social and cultural developments in the region of north-west pre-partition India. This is because, Diamond argues, the majority of Punjabis used multiple languages for different purposes. Diamond seems to understand literacy use in relation to its purpose and domain when he says :

The most common usage of language was within the household and the bazaar. These various uses of languages provided a fluid boundary between those that were spoken, written, read, and understood in the region. (Diamond 2012: 285)

Though noting the fluidity of spoken language in the home and at the market, Diamond's account here neglects the impact this has on the literacies Punjabis had access to at home. He notes that, although there were several written languages in Punjab, Persian was the most significant textual language in the region, though his analysis does not extend to what ordinary Punjabis were doing at home with the literacies that were available to them. Thus, we know that the administrative language of Punjab immediately prior to 1849 was a continuation of practices established during Mughal rule followed by decisions taken by the Sikh rulers of pre-colonial Punjab who also used Persian for written documents, but we are unable to grasp to what extent, 
if at all, these literacies were taken up at home. Diamond tells us that the Punjab was a literacy aware society where the commercial classes and religious leaders had access to various local varieties of language, though he confines his description of the use of 'textual languages' to the fact that:

few people understood or used Sanskrit or Arabic beyond recitation with the exception of religious leaders who maintained control over this knowledge. Still, Arabic terms and phrases were incorporated into Persian, Urdu, and Punjabi, and it was common for Muslims to introduce aiyas (verses) of the Qu'ran into everyday speech. (ibid)

From the analysis of Usman's home literacies, it becomes clear that this process of introducing verses from the Qu'ran into everyday speech also occurred when Muslims introduced verses into their everyday written practices. Usman's family keeps several books related to Islam at home, including copies of the Qur'an in Arabic, religious texts such as the Hadith in Urdu, as well as photocopies of material from other religious texts given to the family by friends and other family members. As the eldest son, it is Usman's responsibility, particularly during religious festivals, to organize readings from these texts at home. During these events, Usman and his father lead the male members of the family in prayer, which involves reading from written texts in Urdu as well as reciting passages from the Qur'an in Arabic which they have committed to memory. There are similarities between Usman's family's Islamic religious practices and the Christian religious practices of the participants in one of the families in Kalman's studies. Kalman, along with Prinsloo and Breier (1996), has argued that putting written texts in the hands of religious 
leaders implies that some individuals have direct access to the sacred through those religious literacies, while others learn about them through oral interpretations. These power relations were also illustrated in Diamond's study of colonial language practices where the dominant languages of Arabic and Sanskrit were partially accessible to Muslim men and women through reading the Qu'ran in Arabic by committing the text to memory both at home and at school. We see an example of what Diamond calls a peaceful 'co-existence between the oral and textual word in this time period for Punjab' in Usman's contemporary home literacies when he and his family gather together to read and recite religious texts given that 'Muslim religious knowledge has been widely accessible in oral societies, and the Qu'ran has had a long history of oral usage.'(2010: 287)

However, the lack of written Punjabi in Usman's household can also be traced back through Diamond's analysis of colonial language policy, where literacy is central. He suggests that British attitudes toward Punjabi were connected to the colonial power's notions of literacy. Diamond's view is that 'the significance and practicability of a language was based upon views of the oral (or 'illiterate') and written (or literate) word. Colonial officials believed that Punjabi predominantly was an oral language, and this belief appeared to be confirmed by 'scientific' studies such as the Census' (2012: 315). This view of a 'great divide' between written and spoken language is a central concern of New Literacy Studies. A social practices approach to literacy posits that within communities of practice, various modes of orality and literacy exist in combination and, as a result, understandings of literacy must include the spoken interaction that goes on around the production and use of texts (Barton and Hamilton 1998). Furthermore, the belief that Punjabi was seen as a dialect of Urdu and not a distinct language in its own right was also prevalent. Indeed, this perspective is common in contemporary Pakistan. In our research 
looking at the language and education context in Pakistan, the misconception that Punjabi was a dialect of Urdu was often given as a reason for not using Punjabi in classrooms (Coleman and Capstick 2012). Thus, Rahman finds that the majority of Pakistanis want to teach Urdu to children in the early years of schooling rather than the local language because it is Urdu, not the local language (if other than Urdu), which provides access to employment and education.

However, Urdu is also used as a lingua franca across multilingual Pakistan. Given its role as the medium of instruction, it is more widespread than English, though, as with English, it is the language of education, employment, trade, and the media (Rahman 2007).

\section{Resisting imposed identities and 'longing to belong' in Britain}

A further theme which can be seen in the dairies is the conflict between positive and negative identities related to what Usman terms 'the West'. Conversations with Usman about the US drone attacks on Pakistan prompted Usman to show me a section of the diary which he had translated into English from Urdu (see Figure 11.3). He told me that he had written the list of identities beginning with the phrase 'I am ...' which he had taken from Dr Zakar Naik, a wellknown television presenter who spoke about religion and, among other things Usman told me, the war on terror.

[insert Figure 11.3 here]

Usman had translated Naik's words as he felt that these identities were 'put on us by the West'. In this sense he is highlighting the negative imposed identities as a means to counter their 
legitimacy; as he told me, 'they are all lies'. However, towards the end of the diary Usman makes fewer entries about religion and nationhood, and grows increasingly preoccupied with the relationships he is developing as a family man, but to a family that lives in another country. Having still not heard whether his second visa application would be successful, Usman's recent marriage to Nadia had resulted in her falling pregnant and the due date of the baby was getting closer. This featured prominently in the final entries in the diary. Alongside a poem which Nadia had written in the diary in English, Usman had also written in English 'Love for Nadia, her beloved husband Usman'. Several short statements such as this reveal Usman asserting his new identity as a husband while at the same time using written English to show his identity as a migrant preparing to live in England. In his home literacies, Usman participates in different relationships with people and asserts different identities.

[insert Figure 11.4 here]

In Extract 4, Usman records his new responsibilities and relationships. The two words that have been redacted are the names of Nadia's children from her first marriage. The extract shows how Usman uses his literacy in English to construct identities as a step-father and husband in Lancashire, but also a son in Mirpur. Usman uses the non-standard varieties of English used in Lancashire: 'them 3 weeks' and 'happiest bloke' which he has spelled 'blok' as perhaps he has only ever heard the word spoken. I interpreted this shift to a variety of English used in his future home as a means to invoke his 'longing to belong' and to construct his belongings, prior to departure, with Nadia and her/his family. 


\section{Conclusion}

In this chapter I have explored the relationship between literacy and home in the literacy practices of Usman while situating Usman's migration within the wider historical context of Mirpuri migration. Beginning with a conceptualisation of 'home literacies' as those literacy practices which converge in the home and are shared among family members and across homes, the study presented here has traced the blurring of boundaries between home and school as well as the blurring of boundaries between homes in Pakistan and homes in the UK. This investigation was enabled by focusing on an approach to literacy which sees literacy as social practice, shaped by the specific cultural, social and political influences on the contexts of use. A narrower focus on the text world of Usman's diaries was brought together with an investigation of the manner in which he uses his diary entries to construct multiple belongings to a range of individuals and communities. Some of the groups to which Usman belongs are constructed by drawing on dominant discourses that connect state, nationhood and language use, such as the importance of Urdu as a unifying force in defining what it means to be a Pakistani. In this sense Pakistan is the home to which Usman belongs, while also belonging to Mirpur and Azad Kashmir. However, Usman wrote his diary entries while he was preparing to join his new wife in the UK. Thus, his diaries reveal the emergence of new belongings to family in Lancashire, England, while still maintaining a sense of belonging to his Mirpuri relatives. Thus, Usman creates multiple belongings to multiple homes and does this by drawing on the languages and literacies that have been made available to him throughout his life.

The text world is for Usman a place to connect the different attachments to people and places and reveal 'a longing to belong' to different homes. Home is therefore central to Usman's literacy practices not only because it is the space in which these practices converge but also 
because it functions as 'the perceived locus of origin as well as the desired destination, the goal, the end' (Papadopoulos 1987: 8). By tracing home literacies in this way, similar findings to those elsewhere in this volume emerge. Firstly, that reaching home is never one directional but rather the longing for home encompasses multiple meanings generated by geographical communities as well as psychological states (Papadopoulos, this volume). Secondly, Rapport's suggestion that individuals may summon a sense of alienation when constructing home, or home in homelessness as he calls it (Rapport, this volume), is also helpful when understanding Usman's home literacies. The disputed nature of Kashmir, the low status of domestic Mirpuri Punjabi, the high status of imported Urdu, and the negative identities related to terrorism are connected in the text world of the diary to Usman's forthcoming migration to England when he both challenges and appropriates different discourses in his home literacies. Thus language and literacy converge in the home, while home literacies become central to the construction of belonging for migrants prior to their departure.

\section{References}

Barton, D. and Papen, U. (2010), 'What is the Anthropology of Writing?', in D. Barton and U. Papen (eds), The Anthropology of Writing: Understanding Textually-Mediated Social Worlds, 3-31, London: Continuum.

Barton, D. and Hamilton, M. (1998), Local Literacies, London: Routledge.

Barton, D. and Hamilton, M. (2000), 'Literacy practices', in D. Barton, M. Hamilton and R. Ivanič (eds), Situated Literacies: Reading and Writing in Context, 7-15, London: Routledge.

Brandt, D. (2001), Literacy in American Lives. Cambridge: Cambridge University Press. 
Blackledge, A. and Pavlenko, A. (2001), 'Negotiation of Identities in Multilingual Contexts', International Journal of Bilingualism, 5(3): 243-259.

Capstick, T. (2016a), Multilingual Literacies, Identities and Ideologies: Exploring Chain Migration from Pakistan to the UK, Basingstoke: Palgrave Macmillan.

Capstick, T. (2016b), 'Literacy Mediation in Marriage Migration from Pakistan to the UK: Challenging Bureaucratic Discourses to Get a Visa', Discourse and Society, 27(5): 481499.

Coleman, H. and Capstick, T. (2012), Language in Education in Pakistan: Policy Recommendations. Islamabad: British Council Pakistan. Available online:

http://www.teachingenglish.org.uk/sites/teacheng/files/Language\%20In\%20Education\%20in\%2 OPakistan.pdf (accessed 8 May 2015)

Diamond, J. M. (2012), 'A 'Vernacular' for a 'New Generation'? Historical Perspectives about Urdu and Punjabi, and the Formation of Language Policy in Colonial Northwest India', in H, Schiffman (ed), Language Policy and Language Conflict in Afghanistan and its Neighbors: The Changing Politics of Language Choice, 282-318, Leiden, The Netherlands: Koninklijke Brill NV.

Fortier, A. M. (2000), Migrant Belongings: Memory, Space and Identity, Oxford: Berg.

Gal, S. and Woolard, K. A. (1995), 'Constructing Languages and Publics: Authority and Representation', Pragmatics, 5 (2): 129-138.

Gee, J. P, (2011), An Introduction to Discourse Analysis: Theory and Method, London: Routledge.

Krzyzanowski, M. and Jones, P. (2008), 'Identity, Belonging and Migration: Beyond 
Constructing Others', in G. Delanty et al. (eds), Identity, Belonging and Migration, 329Liverpool: Liverpool University Press.

Kalman, J. (2005), Discovering Literacy: Access Routes to Written Culture for a Group of Women in Mexico, Hamburg: UNESCO Institute for Education.

Lothers, L. and Lothers, M. D. (2007), Pahari and Pothwari: A Sociolinguistic Survey (FLI Language and Culture Series, 2), Peshawar, Pakistan: Frontier Language Institute. Papadopoulos, R. (1987), Adolescents and Homecoming, London: Guild of Pastoral Psychology.

Prinsloo, M. and Breier, M. (1996), (eds), The Social Uses of Literacy, South Africa: John Benjamins.

Probyn, E. (1996), Outside Belongings, Routledge New York, NY: Routledge

Rahman, T. (1997), 'The Medium of Instruction Controversy in Pakistan', Journal of Multilingual and Multicultural Development, 18 (2): 145-154.

Rahman, T. (2009), Linguistics in Pakistan: A Survey of the Contemporary Situation. Rahman, T. (2005), Linguistics in Pakistan: A Survey of the Contemporary Situation, in D. Inayatullah, R. Saygol and P. Tahir (eds), Social Sciences in Pakistan: A Profile, 9-30, Islamabad: Pisces Enterprises.

Rassool, N. (2007), Global Issues in Language, Education and Development: Perspectives from Postcolonial Countries, Clevedon, Avon: Multilingual Matters.

Street, B. (1984), Literacy in Theory and Practice, Cambridge: Cambridge University Press. 